\section{ÚJ LEHETŐSÉGEK A BIZTOSÍTÁSI INNOVÁCIÓBAN}

A KPMG International kiadványa alapján az összefoglalót készitette: Leposa Csilla és Hanák Gábor (KPMG Tanácsadó Kft., csilla.leposa@kpmg.hu, gabor.hanak@kpmg.hu). Az angol nyelvü verzió az alábbi linken elérhetö: https://home.kpmg.com/xx/en/home/insights/2015/09/the-insurance-innovation-imperative.html

\section{ÖSSZEFOGLALÓ}

A biztosítók és a biztosításközvetítők a jövőben nem tehetik „„öbbé-kevésbé ugyanazt, csak gyorsabban”, ha növekedni szeretnének. A technológia és az innováció új kihívásokat és lehetőségeket teremtett az egyének, az üzleti világ és a társadalom számára. Az ügyfelek, a befektetők és az alkalmazottak egyaránt kikövetelik az innovációt, és nemcsak a technológiai iparágaktól, hanem a biztosítási szektortól is.

Az iparágat érintő lehetőségek és a hatások feltérképezése érdekében a KPMG egy online felmérést készített a biztosítási szakma szenior vezetőinek körében, 280 cég bevonásával 20 országban, 2015 áprilisában. A megkérdezettek szektorprofilja a következő volt: 25 százalék élet- és egészségbiztosító, 23 százalék vagyon- és balesetbiztosító, 29 százalék kompozit és 23 százalék egyéb.

elen cikk, amely ennek a felmérésnek az eredményeit foglalja össze, kiegészítve a KPMG szakértőinek észrevételeivel, azt emeli ki, hogy a jövő kihasználása érdekében a biztosítási iparágnak el kell mozdulnia a tradicionális kockázatkerülő megközelítéstől a kockázatokat szétterítő, ugyanakkor a kísérletezést is ösztönző müködési kultúra irányában.

\section{SUMMARY}

Insurers and intermediaries can no longer do „more of the same” and expect to grow. Technology and innovation have created a new word of opportunity for individuals, business and society. The reality is that customers, investors and employees demand innovation. Indeed, they expect it, not only for technology providers and device manufacturers, but also from insurance organizations.

To explore these opportunities and potential impacts rising for the industry, KPMG conducted an online survey with senior insurance executives, augmented with commentary from some of the world's most forward-thinking insurers, reinsurers, intermediaries, start-ups and disrupters. The online survey was conducted in April 2015 with 280 insurance industry executives across 20 countries. Sector profiles include: 25\% Life and Health, 23\% Property and Casualty, 29\% Composite and 23\% other.

This article - summarizing the findings of the above survey, combined with insights from KPMG network of professional - underscores that, in order to make most of the future ahead, the industry needs to pivot from a traditionally risk-averse culture to one that encourages experimentation while mitigating risk.
Kulcsszavak: biztosítás, innováció

Keywords: insurance innovation

JEL: G22, O30

DOI: $10.18530 /$ BK.2017.1.38

http://dx.doi.org/1018530/BK.2017.1.38

\section{Előszó}

A technológiai fejlődés az egyének, a vállalatok és a társadalom számára egyaránt új lehetőségeket teremtett. Kevésbé nyilvánvaló ugyanakkor, hogy a jövőt azok fogják alakítani, akik ma innovatívak. A biztosítási szektor számára ez nem pusztán tény, hanem kiemelten fontos feladat is.

Jelenleg az ügyfelek, a befektetők és a munkavállalók egyaránt elvárják az innovációt. Ez az igényük nemcsak a technológiai szolgáltatók és eszközgyártók felé mutatkozik meg, hanem a biztosítószervezetek felé is. A biztosítási szolgáltatók többé már nem végezhetik a feladatukat „többé-kevésbé ugyanúgy ugyanazt” elven, miközben várják a növekedést.

Az innováció ösztönzésére való reagálás nem könnyű feladat. Nem létezik egyszerü csodaszer egy még innovatívabb szervezet létrehozására; nincsen „kész csomag”, amely új ötleteket generál. Helyette a biztosítóknak és a közvetítőknek a saját útjukat kell járniuk, a lehetőségek ezen új tárházát ki kell használniuk az új vállalkozások, operációs modellek és új partneri kapcsolatok fejlesztésében azért, hogy versenytársaikat, valamint a piacra újonnan belépő szereplőket legyőzzék, és az innováció területén megelözzék.

Egy új ösvény kitaposása innovációs szempontból nem azt jelenti, hogy a nulláról kell kezdenünk. Azt kell mérlegelni, hogyan használjuk ki a bizonyítottan nyerő ötleteket és tapasztalatokat, beleértve mások elgondolását is azért, hogy általuk új szemléletet és javaslatokat teremtsünk, amelyekkel az ügyfelek tetszését elnyerhetjük, és értéket teremthetünk. Az útkeresés arról szól, hogy mind a tradicionális, mind a piacon újonnan megjelenő versenytársaktól tanuljunk, ugyanakkor arról is, hogy bátran kölcsönözzük a legjobb gyakorlatokat és új ötleteket más, akár nem a biztosítási szektorhoz és annak hagyományos szövetségeseihez tartozóktól is.

\section{Az innováció sürgős és fontos}

A biztositók és a közvetítők tudatában vannak annak, hogy csakis innováció útján javíthatnak üzleti és operációs modelljükön, és csakis úgy védhetik meg magukat és növekedhetnek, ha gyorsabban újítanak, mint a versenytársaik. A felmérés eredményei szerint a biztosítók többsége az operációs innovációra összpontosít inkább, semmint a stratégiai innovációra. 
A biztosítók és a közvetítők számára egyértelmű a közvetlen kapcsolat az innováció és a növekedés között. Tíz megkérdezettből nyolc hisz abban, hogy szervezetük jövőbeni sikere jelentősen függ attól, képesek-e megelőzni versenytársaikat az innovációban.

\section{A biztosítók többsége az operációs innovációra \\ összpontosít inkább, semmint a stratégiai innovációra.}

Érdekesség, hogy a nagyobb szervezetek (több mint 5 milliárd USD bevétellel rendelkezők) nagyobb valószínűséggel kötötték össze a sikert az innovációval, mint kisebb társaik. A vagyon-, baleset-, valamit a kompozit szektorhoz tartozó válaszadók jobban koncentrálnak az innovációalapú növekedésre, mint az élet- és egészségszektorhoz tartozó társaik.

A különféle adatbázisok és a digitalizáció potenciális lehetőségeinek kombinációja szintén innovációösztönző lehet. Sok szervezet gondolja úgy, hogy a technológia jobb kihasználása több újítást és nagyobb növekedést ösztönöz. A felmérésünk válaszadóinak több mint fele állította, hogy a digitális technológia és annak üzleti célkitűzésekbe való beépülése egyike a szektorukon belüli három legnagyobb növekedési lehetöségnek. (Ld. az 1. ábrát) A válaszadók negyede a digitális technológiát látja a legnagyobb növekedési lehetöségnek a következő két évben.

1. ábra: Melyek a legnagyobb lehetőségek egy szervezet számára a következő két évben?

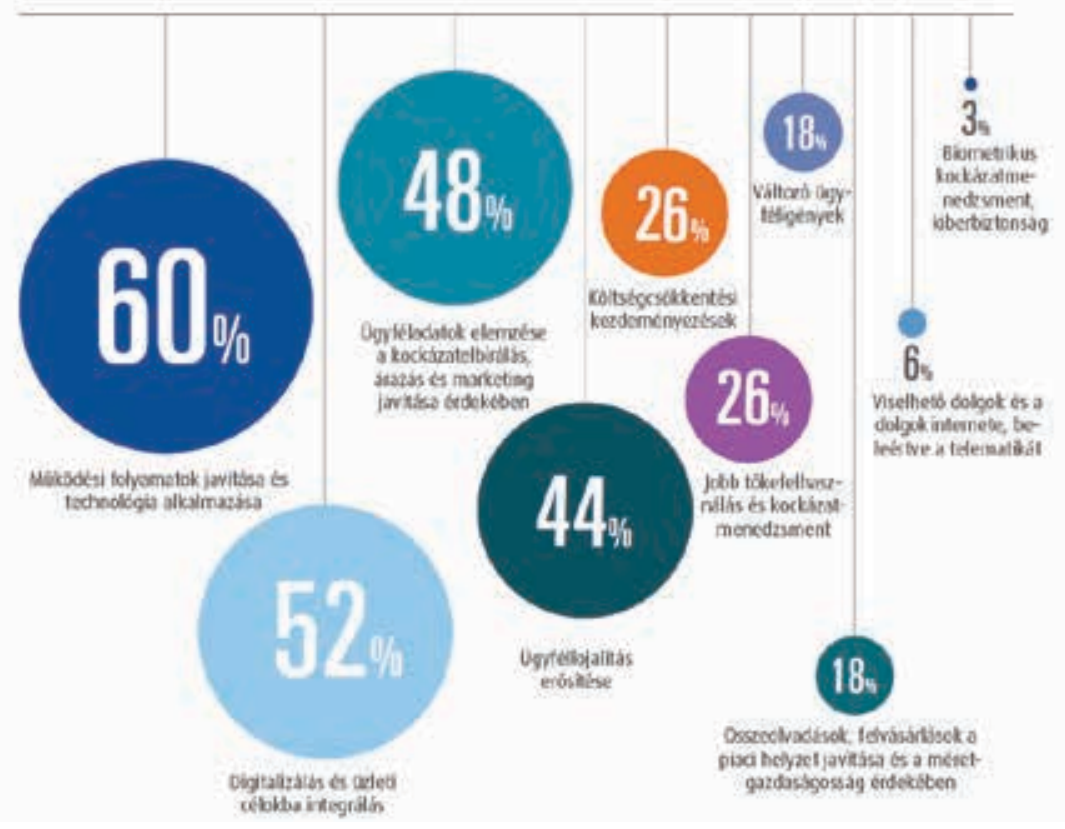

Forrás: $K P M G$
Az adatok azt mutatják, hogy a digitalizáció mértékét tekintve az észak-amerikai szervezetek lemaradtak az európai és ausztrál társaikhoz képest. Észak-Amerikában csak a válaszadók 38 százaléka mondja azt, hogy lehetőséget lát a digitalizálásban, szemben az ausztrálok 61 és az európaiak 55 százalékával.

A technológiára általánosságban a növekedés egyik elősegítőjeként tekintenek, ugyanakkor legtöbben a jobb szolgáltatást és a nagyobb hatékonyság motorját is látják benne. Az összes válaszadó 60 százaléka szerint a technológia használatának elmélyítése a három legiobb lehetőség egyike. Talán nem meglepő, hogy leginkább a közepes méretű vállalatokra (500-5000 millió USD bevétellel rendelkezők) jellemző, hogy a technológia a legnagyobb lehetőség számukra, hiszen sokan közülük valószínűleg csak most kezdenek el technológiai fejlesztésekkel foglalkozni.

A felmérés eredményei és a tapasztalatok egyaránt azt jelzik, hogy néhány válaszadó talán túlságosan a növekedési, operációs innovációra összpontosít a stratégiát támogató, piacformáló innováció helyett. Mindössze a válaszadók 6 százaléka véli úgy, hogy a következő két év növekedési stratégiájában arra fókuszál majd, hogy teljesen új termékeket és szolgáltatásokat kínáljon a már meglévő vagy új ügyfélszegmensnek. Ezzel szemben 31 százalékuk számára elsődlegesen a már meglévő termékek és szolgáltatások javítása a cél.

Számos biztosító és közvetítő azonban felismerte, hogy radikálisabb újítások kellenek ahhoz, hogy az új versenytársakkal szemben megvédjék magukat, és további üzleti növekedést érjenek el. Világszerte a válaszadók kicsivel több, mint egynegyede (26\%) állította, hogy elsődleges növekedési stratégiájuk új termékek és szolgáltatások fejlesztésére összpontosít, de ezek a már létező szolgáltatáspalettájukhoz kapcsolódnak.

\section{KPMG-megállapítás:}

- Az innovációnak a növekedésösztönzésre kell fókuszálnia. Az ügyfél-elégedettség növelése történhet hatékonyságnöveléssel, új ügyfélközpontú termékek és szolgáltatások, valamint új csatornák bevezetésével, illetve szemléletváltással.

- Az operációs hatékonyság javítása alapvető. Ahhoz azonban, hogy igazi versenyelőnyt jelentsen az innovácó, a biztosítóknak és a közvetítőknek át kell tekinteniük a tevékenységüket az értékesítési csatornáktól kezdve a marketingen és az üzleti modellen át egészen a kapcsolatokig.

Ma a digitálisan fejlett ügyfelek (mind a B2C, mind a B2B) folyamatos innovációt, jobb hozzáférést és szolgáltatást igényelnek. Azokat, akik nem elég fejlettek (vagy nem hajlandóak fejlődni), és nem tesznek eleget a változó ügyfélkövetelményeknek, hamar túlszárnyalják a gyorsabb és innovatívabb versenytársak.

- A digitális csatornák átalakítják a meglévő pozíciókat, új típusú küzdelem alakul ki a már meglévő ügyfelek megtartásáért és az újak szerzéséért. 


\section{Szükséges intézkedések:}

- Gondolkodjon el azon, hogy mit vár az innovációtól, majd tervezze meg, hogyan kapcsolja össze a forrásokat, az adatokat, a technológiát és a képességeket a célok elérése érdekében!

- Lépjen túl az operatív változásokon, és fókuszáljon a növekedésre! Gyakran a kettő együtt jár ugyanis, az online jelentkezési űrlapok bevezetése például javíthatja a hatékonyságot.

- Fontolja meg, hogyan lehet a legjobban összekapcsolni a hosszú távú és kockázatosabb projekteket a rövidebb távú, gyorsabban nyereséget hozó kezdeményezésekkel!

- Gondolkodjon el azon, hogyan tehetné egyszerűbbé a biztosítási termékeit az ügyfelei számára (akármennyire intelligensek is), és hogyan alakíthatná át a szervezetét olyan piaci szereplővé, akivel egyszerü üzletelni.

- Járjon a piaci trendek előtt, és kezdeményezzen az ügyfeleinél, akiket kiszolgál! Ez az új technológiák hatékonyabb használatát teheti lehetővé, ami viszont új termékek és szolgáltatások fejlesztését generálhatja.

\section{Váratlan események a piacon}

A megzavarás (olyan üzleti magatartás, amely mások megszokott üzletmenetében képes nem várt, esetleg kedvezőtlen hatást okozni) a biztosítási szektor számára még erősebb versenyt jelent. Új belépők, új technológiák és új üzleti modellek egyre gyorsabb ütemben jelennek meg a piacon. A biztosítóknak a rövid és a hosszú távú lehetőségekre egyaránt figyelniük kell, csakúgy, mint a lehetséges kockázatokra, zavart keltő tényezőkre és az innovációra. Mindez feltétele annak, hogy hosszú távon értéket teremtsenek.

\section{Ötletgazdag FinTech versenytársak megpróbálhatják} aláásni és megzavarni a status quót.

Jelen pillanatban nem tünik valószínűnek, hogy az Apple vagy a Google váratlan belépést tervezne a biztosítók online piacára, viszont más, hasonlóan ötletgazdag FinTech (Financial Technology - pénzügyi informatikai technológia) versenytársak megpróbálhatják aláásni és megzavarni a status quót. Sok biztosító már érzi ennek a hatását.

A felmérés válaszadóinak majdnem a fele mondja azt, hogy az üzleti modelljüket már zavarja egy új, ötletesebb versenytárs, és sokan egyértelműen aggódnak amiatt, hogy az innováció több kellemetlenséget, mint értéket hoz. Érdekességképpen: az észak-amerikai válaszadók jóval nagyobb valószínűséggel állítják, hogy tapasztaltak ilyet, mint európai társaik, és valamennyivel nagyobb valószínűséggel élnek is vele, mint ázsiai társaik.

Az eredmények azt sugallják, hogy a nagyobb szervezeteket érzékenyebben érintik a piaci zavarok. A kisebb szervezeteknek csak a 39 százaléka mondta, hogy tapasztalt már hasonlót, szemben a nagy szervezetek 54 százalékával. Az élet- és egészségbiztosító szervezetek a vagyon- és balesetbiztosítási szervezetekhez képest kisebb kellemetlenségeket észleltek.

A megnövekedett verseny - mind az új belépők, mind az agilisabb vállalatok képviselői részéről - kihívásokat teremt a biztosítók számára az egész világon. A válaszadók közül tízből négy nyilatkozta azt, hogy az ismert vetélytársak részéről generált verseny kihívásokat teremthet az elkövetkező két év során. 28 százalékuk számít arra, hogy a nem tradicionális szolgáltatást nyúitók miatt jelentős kihívásokkal kell szembenézniük. (Ld. a 2. ábrát)

2. ábra: Melyek szervezetének legnagyobb kihívásai a következö két évben?

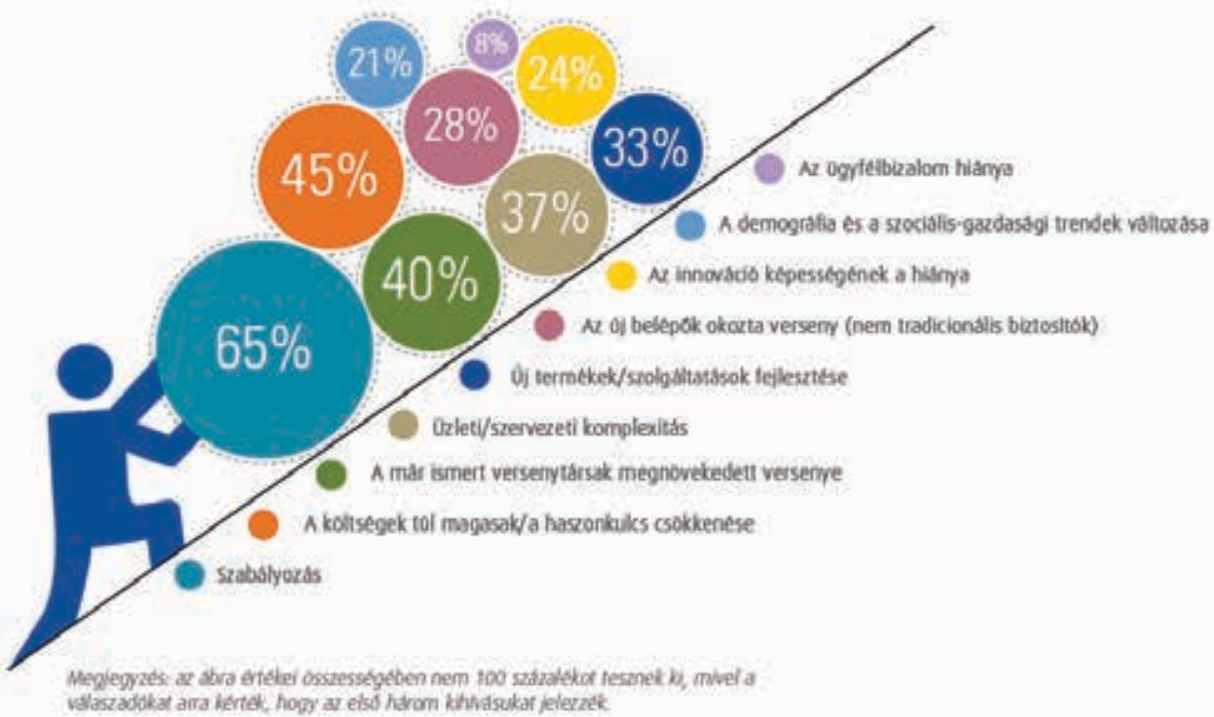

Forrás: KPMG

Különösen az észak-amerikai válaszadók aggódnak az új versenytársak jelentette fenyegetettség miatt. Az új versenytársakat kétszer annyian említették fő kihívásként, mint európai székhelyü társaik. A vagyon- és balesetbiztosítási szektor szereplői is jobban aggódnak az új versenytársak megjelenése miatt, mint az élet- és egészségszektorhoz tartozó társaik.

Úgy tűnik, hogy míg az észak-amerikai válaszadókat nagyon is aggasztja a már meglévő vetélytársak (az új versenytársak megjelenésén felül) erőteljesebb versenye is, addig az ausztrál szervezetek jobban tartanak attól, hogy az új versenytársak meg fogiák előzni őket. Szemben az élet- és egészség-, valamint a kompozit szektorhoz tartozó válaszadókkal, ismét a vagyon- és balesetbiztosítási szektor válaszadói tartották a legvalószínủbbnek, hogy a már létező versenytársak részéről megnövekedett verseny rövid távú kihívásokat fog teremteni. 


\section{KPMG-megállapítás:}

- $\quad \mathrm{Az}$ innovációt nem lehet légüres térnek tekinteni. Ahogyan egy vállalat azon dolgozik, hogy újítson, a versenytársai ugyanezt teszik. A stratégiáknak rugalmasnak kell lenniük, hogy gyorsan reagálhassanak a versenykörnyezet változásaira.

- Az üzleti modellek egyre növekvő változása figyelhető meg, ahogy a digitális technológiák és a mobilfizetések csökkentik a működési költségeket, és gyengítik a versenyelönyt.

- Nem lehet figyelmen kívül hagyni, hogy az új versenytársak megjelenése bármikor megzavarhatja a piac mủködését. Amint John Geyer a MetLife-tól találóan megfogalmazta, ha valaki megzavarja az üzleti tevékenységedet, az lehet, hogy te magad leszel.

- A nagyobb szervezetek számára több forrás áll rendelkezésre innovációs célra, viszont a legtöbbjük régi beidegződésektől szenved, és rossz szervezeti struktúrák is akadályozzák a gyors reagálást. Elképzelhető, hogy a nagyobb szervezetek rövid távú hátránnyal néznek szembe, összehasonlítva őket a kisebb vagy újabb versenytársakkal.

- Lehet, hogy a globálisan sokszínűbb szervezeteknek több fronton is kihívásokkal kell szembenézniük az új versenytársak miatt. Különösen a nemzetközi vagyon- és balesetbiztosítóknak kell majd ádáz versenyre készülniük.

\section{Szükséges intézkedések}

- Tegye rugalmassá és gyorssá az innovációs stratégiáit és folyamatait, hogy gyorsan reagálhasson az új versenykihívásokra és lehetőségekre!

- Elemezze a vállalati szervezet gyenge pontjait, a melyek az új belépőknek lehetőségeket kínálhatnak! Fejlesszen ki stratégiákat, amelyekkel elsőként védheti, illetve felügyelheti ezen üzleti területeket!

- Ahelyett, hogy minden új, felbukkanó versenytárs kihívását elhárítaná, gondolja végig, hogyan nyerhet meg magának olyan innovátorokat, és dolgozhat velük együtt, akikkel javíthatja versenyképességét!

- Figyelje a felbukkanó új versenytársakat és FinTech szereplöket, akikkel érdemes lehet együttmüködni

- Elemezze a biztosításon kívüli partnerekkel való együttműködés lehetőségét! Például az autóiparban, technológiai szektorban és a telekommunikációban megjelenő fejlesztések hatnak a gépjármü-biztosítási módozatokra is, így az ezekkel az iparágakkal való együttműködés felgyorsíthatja az ügyfélelőnyök felismerését, és kiterjesztheti az értékláncot.

\section{Az innovációra való hajlandóság}

Világszerte egyre több jövőbe tekintő biztosító és közvetítő reménykedik abban, hogy az új versenytársak megjelenése miatt magasabb fokozatra kapcsolhatnak az újításért folyó versenyben. A változás korának küszöbén járunk - ezt sejtetik azok, akik jól elkülönített költségvetéssel és innovációs kerettel bírnak.

Ha elfogadjuk, hogy az innovációs költségvetéssel és a teljes vállalatra kiterjedő, az újítások kihívásaira készülő stratégiákkal rendelkező szervezetek a biztosítási innováció éllovasai, akkor a fejlettebb szervezetek már arra a versenyre készülnek, amelyet az innováció hoz magával. A válaszadóink közül azok, akik formalizált innovációs stratégiával rendelkeznek, több mint kétszer nagyobb valószínüséggel mondták, hogy az elsődleges fókuszuk az ügyfélszükségletek és szegmensek számára vonzó új ajánlatok kifejlesztése volt, semmint az operációs folyamataik javítása.

A felmérés elörevetíti továbbá, hogy azok, akik már most is költenek az innovációra, még inkább növelik az erőfeszítéseiket a jövőben. Az ebből fakadó növekedés az innovációs költségvetéssel már rendelkezők 93 százalékának állítása szerint látszódni fog a következő két évben, szemben a maradék 7 százalékkal, akik arra számítanak, hogy az erre irányzott költségvetésük szükül majd. Az adatok azt mutatják, hogy a nagyobb szervezetek nagyobb valószínűségét látják a költségvetési keret bővülésének, mint kisebb versenytársaik.

Néhányan ugyanakkor úgy vélik, hogy a biztosítók és közvetítőik igényeit tekintve a jelen szakaszban az újítások föleg a back-office folyamatok fejlesztésére fókuszálnak, mintsem új termékek és disztribúciós csatornák kialakítására.

A közepes méretű cégek válaszaiból kitűnik, hogy jobban koncentrálnak az új termékek kifejlesztésére, mint kisebb és nagyobb társaik. Amennyiben ezek a szervezetek az új fejlesztésekbe invesztált erőforrásokkal arányos volumennövekedést érnek el, és mindemellett továbbra is kreatívak maradnak, ez azt jelentheti, hogy a közepes méretű vállalatok képesek lesznek a nagyobb és a kisebb versenytársaikat is megzavarni.

\section{KPMG-megállapítás:}

- Azok, akik az innováció területén már előnyre tettek szert, továbbra is keményen küzdenek, hogy fejlődési pályán maradjanak. Könnyen lehet azonban, hogy azok a vállalatok, amelyek még csak ezután fognak bele az újításokba, lemaradnak, amint az innováció léptéke felgyorsul.

- A jövőbeni verseny kevésbé szól majd arról, hogy a nagyok megelőzik a kicsiket, sokkal inkább a gyorsaság lesz a fontos. Az agilisabb szereplők számára így soha vissza nem térő lehetőségek kínálkozhatnak, amelyekből további lendületet tudnak nyerni, a hagyományos szereplők pedig esélyt kapnak, hogy újból feltalálják magukat. 
- Az innovációra elkötelezett költségvetés és az átfogó innovációs stratégia kulcsfontosságú az innovációorientált növekedés ösztönzése szempontjából.

A beruházásoknak rövid és középtávon is nőniük kell. Mint a legtöbb átalakításra irányuló projektnél, itt is igaz az, hogy pénzt kell költenünk ahhoz, hogy pénzt kereshessünk.

\section{A jövőbeni verseny kevésbé szól majd arról, hogy a nagyok megelőzik a kicsiket, sokkal inkább a gyorsaság lesz a fontos.}

\section{Szükséges intézkedések:}

- Fejlesszen ki egy formális innovációs stratégiát, amely egyértelmü útmutatást, célokat és sarokpontokat tartalmaz!

- Biztosítsa a költségvetés hosszú kifutását - legyen az akár üzletiegység-, akár csoportszintű - a hosszú távú ötletek kibontakozása érdekében!

- Támogassa azt a vállalati kultúrát, amelyben lehetőség van kísérletezni, hibázni, ezekből tanulságokat levonni, és mindezt úgy, hogy elfogadható sarokszámokhoz igazított megfelelő ösztönzők segítsék a kulcsszereplőket!

\section{A hiányzó rajtvonal}

Míg sok biztosító felismeri, hogy az innovációs lehetőségekkel új világ nyílik meg, úgy tűnik, sokan vonakodnak az első lépések megtételétől.

Ez nem teljesen meglepő, hiszen a válaszadó szervezetek többsége az innovációra elkötelezett költségvetésnek, a formális stratégiák meglétének, illetve a vezetői szintű támogatás és teljesítmény-mérőszámok kijelölésének hiányát jelölte meg ennek okaként.

Feltéve, hogy a legtöbb biztosító és közvetítő felismeri a kapcsolatot az innováció és a növekedés között - márpedig úgy tűnik, hogy a válaszadók többsége nagyon is aggódik az új belépők és az innovatívabb versenytársaktól való fenyegetettség miatt -, kissé meglepő, hogy csak kevesen készek arra, vagy mutatnak érdeklődést afelé, hogy megragadják az első lépésből származó előnyt.

Valójában a válaszadóknak csupán a 32 százaléka állította, hogy szervezetükre úgy tekintenek, mint akik az innovációban élen járnak, míg 40 százalékuk elégedettnek tűnt azzal is, hogy gyors követő szerepet tölt be. Az összes válaszadó több mint negyede azt jelezte, hogy nincs felismerhető filozófiájuk az innovációt illetően.

A közepes méretű társaságok nagyobb hajlandóságot mutattak az innovációra, kisebb társaiknál mintegy 25 százalékkal nagyobb valószínűséggel sorolták magukat azok közé, akik az első lépést megteszik. Az ausztrál válaszadók hajlandóbbnak mutatkoztak az első lépésből származó előnyök kiaknázására, mint más régiókban működő társaik.

A tapasztaltak szerint mindössze néhány biztosító mutatja az innovációs szervezetre jellemzőket, és lehet, hogy közülük is csak kevesen készek arra jelenleg, hogy hosszú távon újításokat vezessenek be.

Érdemes megfigyelni például, hogy az összes válaszadó kevesebb mint fele (47\%) mondta, hogy rendelkeznek egy már létező, a teljes vállalatra kiterjedő innovációs stratégiával, és csak 39 százalék tett említést az innovációra vonatkozó költségvetés meglétéről.

\section{Mindössze néhány biztosító mutatja az innovációs szervezetre jellemzőket.}

Úgy tűnik, sok válaszadó küzd a vezetőséggel az innovációs programok támogatásának elnyeréséért - ami a siker egyik kulcsa -, és kevesebb mint negyedük mondja, hogy rendelkeznek olyan felelős munkatárssal, akinek az újítások ösztönzése a feladata.

A kifinomult innovációs stratégia egyéb ismertetőjelei is gyakran hiányoznak. A válaszadók kevesebb mint negyede állítja, hogy nagy adatállományt és adatelemzést használnak az innovációs programok és döntések ösztönzésének elősegítésére. Ötből egy vallotta, hogy nincs kialakult eljárásuk az innovációra fordított beruházás megtérülésének a mérésére.

Az innováció fontosságával azonban felsőbb szinteken tisztában vannak. A válaszadóknak csak 20 százaléka nem tudott arról, hogy a vezetőségben milyen gyakran tárgyaltak az innovációról.

\section{KPMG-megállapítás:}

- A szervezeteknek megalapozott döntést kell hozniuk arról, hogy elsőként tegyék meg a lépést, vagy gyors követők legyenek a kockázatvállalási hajlandóságot, a teremtő értékeket és a képességet számba véve.

- Biztosítók az innováció alapjai nélkül - úgymint vezetőségi támogatás, elkülönített beruházási forrás, formális stratégiák és új képességek - küszködni fognak a versenyben, ha hirtelen változások következnek be

- Elképzelhető, hogy azok, akik kisebb piacokon működnek, vagy korlátozott beruházási költségvetéssel bírnak, a kialakulóban lévő technológiák gyors bevezetésére akarnak összpontosítani a változásból adódó lehetőségek kiaknázása végett.

- Néhány biztosító az innovációs központok és laborok létrehozásával kísérletezik, ám hiába tudja a szemléletmód változása felgyorsítani az egyéni ötletek felszínre kerülését, ha ez önmagában nem támogatja a széles körű vállalati innovációs kultúrát.

- Félreértés, hogy az innováció újszerű gondolkodást igényel, és hogy a nagyszerű gondolatok az innováció számára megfelelő környezet kialakítását követik. A valóságban az innováció maga egy folyamat, amelyben az eszközök és az infrastruktúra megléte nagyobb valószínűséggel vezet sikerhez, mint az, hogy teret engednek az ötleteknek. 


\section{Szükséges intézkedések:}

- Értékelje szervezetének képességét, hogy gyorsabban és nagyobb következetességgel újítson, mint versenytársai! Maradjon reális annak megítélésében, hogy mire érdemes törekednie: elsőként lépjen, vagy gyors követőként viselkedjen!

- Összpontosítson egy erős és fenntartható innovációs program kialakítására, mint a formális stratégiák, az elkötelezett költségvetés, a sarokszámok és a világos célok meghatározása. - Folyamatosan figyeljen az ügyféligények proaktív kielégítésére és a FinTech vagy más, szektoron kívüli, piaci zavarokat okozó szereplőkre!

\section{Szembenézni a mindennapos kihívásokkal}

A legtöbb biztosító tisztában van az újítás szükségességével, ugyanakkor a túlnyomó többségnek komplex innovációs dilemmával kell szembenéznie a képességek, kapacitások és a költségek tekintetében. Míg sokan azt mondják, hogy tettek már lépéseket az innováció ösztönzése érdekében, a tapasztalatok szerint kevesen elég bátrak.

\section{Úgy tünik, a tehetségek hiánya is visszatartja \\ a biztosítókat az innovációtól.}

A szektorban sok, jelenleg is zajló változás miatt - ami nemcsak az innovációt, hanem az új szabályozásokat és az ügyfelek részéről érkező új kéréseket és elvárásokat is magába foglalja - úgy tünik, csak néhány biztositó rendelkezik idővel vagy kapacitással, hogy új projekteket vállaljon. Világszerte a megkérdezettek 79 százaléka (3. ábra) válaszolta, hogy jelenleg is csak teljes fokozatra kapcsolva tudnak eleget tenni az alapvetö követelményeknek.

Érdekesség, hogy a nagyobb szervezetek és a kompozit biztosítók egyaránt úgy gondolják, hogy társaikhoz képest kisebb kapacitáshiányban szenvednek, szemben a vagyon- és balesetbiztosítókkal, akik gyakrabban szembesülnek ezzel a problémával.

Úgy tűnik, a tehetségek hiánya is visszatartja a biztosítókat az innovációtól. A képességek és az adottságok hiányát a válaszadók 74 százaléka említette az innovációt gátló első három tényező között. Különösen igaz ez a kisebb vagy a közepes méretű szervezetekre és azokra, amelyek Európában működnek.

Kevés válaszadó mondta, hogy szervezete elkötelezett innovációs költségvetéssel rendelkezik, így talán nem meglepő, hogy a felső vezetéshez tartozó válaszadók a befektetés hiányát és a költségteher emelkedését tartották az innováció legfőbb akadályának.

A válaszokból úgy tűnik, hogy a biztosítók már számos stratégiával próbálkoztak az innováció vállalati szinten való javítása érdekében. Sokan összpontosítottak a szervezetük ismereteinekés képességeinek bővitésére annakérdekében, hogy innovatívabbak legyenek: 51 százalék mondta azt, hogy elindítottak már valamilyen, a vállalati kultúra változását támogató programot, míg 36 százalék nyilatkozott úgy, hogy ötletfejlesztési és innovációs tréningeket vezettek be.
Néhányan az innovációs ökorendszerük kiszélesítésére fókuszálnak. 43 százalék állította, hogy partneri kapcsolatot ápolnak akadémikusokkal, FinTech-szervezetekkel és más harmadik féllel az innováció ösztönzésének érdekében: 34 százalékuk ezzel külső vállalatot bízott meg, vagy kiszervezte az innovációs feladatokat. Mások az üzleti modelljüket és szervezeti struktúrájukat változtatták meg a fejlődés ösztönzése végett, beleértve egy 100 százalékban elkötelezett innovációs csapat összeállítását is. A tapasztalatok azonban azt sugallják, hogy ezeknek a kezdeményezéseknek hiába van létjogosultságuk, csak néhány szervezet elég merész a vízióban vagy a kivitelezésben, amelyek igazán ösztönöznék a változást.

3. ábra: Mely szervezetének legfőbb három belső innovációs kihívása?

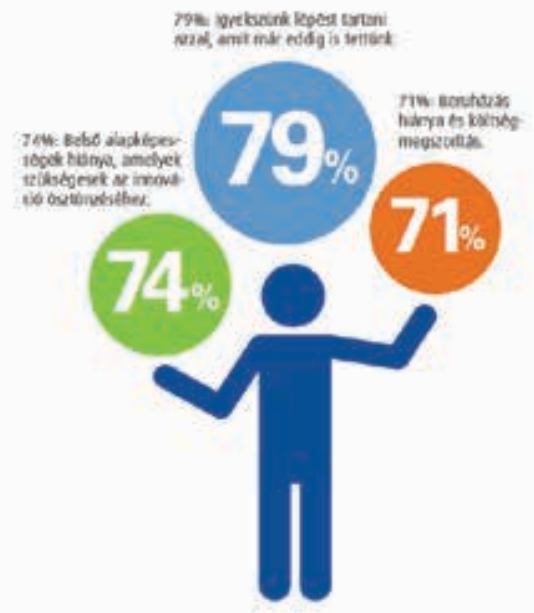

Forrás: KPMG

\section{KPMG-megállapítás:}

A biztosítóknak és a közvetítőknek arra kell összpontosítaniuk, hogy lehetővé tegyék a képességek, a kapacitás és a tőke megfelelő kombinációját az innováció hosszú távú ösztönzése érdekében. Ez magába foglalja azoknak az új megoldásoknak a megtalálását is, amelyek a régi rendszerek és adatkezelési folyamatok ellenére is támogatják az innováció növelését.

- A partneri együttműködések kulcsfontosságúak lesznek a jövőben a sikerhez, de szükség van a megfelelő struktúrákra, modellekre és infrastruktúrára az értékteremtés érdekében.

- Egyszerűen azzal, hogy kulturális változást célzó programokat szervez valaki, még nem biztos, hogy a kívánt eredményt éri el. Ezek ugyan szükséges kezdeményezések, 
de a már futó programokat és eredményeket is a szervezet részévé kell tenni, mintsem csak divatként kezelni, amely hamar a feledés homályába vész.

- A gondolatok sokféleségének ösztönzése az innováció elindításának egyik kulcsa.

\section{Szükséges intézkedések:}

- Folytasson alapos értékelést a rendelkezésre álló infrastruktúráról, tehetségekről és képességekről a meglévő források maximális kihasználása érdekében!

- Fontolja meg az információtechnológiai rendszerek használatát és a munkavállalói ösztönző programokat, amelyekkel javítani tudja mind a szakmai, mind a személyes képességeket!

- Fedezze fel a lehetséges partnerei és az együttműködési modellek széles körét az innovációs beruházás maximalizálása végett, tegye könnyebbé az új ötletek és tehetségek elérését!

- $\quad$ Nem jó megoldás, ha kiszervezzük az innovációt technológiailag fejlettebb közreműködők számára. Az innovációs folyamatnak, mint a vállalati kultúrát érintő minden változásnak, felülről irányítottnak kell maradnia.

- Folyamatosan kell digitalizálni a fö folyamatokat, és új üzleti modelleket feltárni, amelyeket a digitális technológiák képesek kezelni.

\section{Az innováció világa}

Ahhoz, hogy többet tudjunk meg arról, mit jelent az innováció az érett szakaszban lévő biztosítók és közvetítők számára, három szervezet személetmódját vizsgáltuk meg.

1. A megfelelö egyensúly megtalálása az innovációhoz Az innováció elösegitésének alapfeltételei

- A vezetőségnek a változás szükségességét helyesen kell megítélnie. Az igazgatótanácsnak és a vezetői csapatnak fel kell ismernie, hogy a szervezetük jövőbeni növekedése azon képességüktől függ, hogy ezekre a változásokra milyen határozottan reagálnak.

- Vezetés és megfelelő vállalatirányítás: egy újító szemléletű vállalati kultúra igényli a vállalatirányítás fejlődését, amely a megfelelő képességek beillesztésére összpontosít. Ezáltal változásra és gyorsaságra ösztönöz, és nem statikus módon közelíti meg az innováció felelösségének kérdését.

- Meg kell bizonyosodni arról, hogy világos iránymutatással rendelkezünk, amely egyértelművé teszi, hogy mikor milyen eszközt kell igénybe venni, milyen irányítási modellek és milyen beruházások szükségesek a fejlesztés és a gyártás innovációs gépezetének olajozott müködtetéséhez.

\section{Az ügyfél középpontba helyezése}

- A biztosítóknak meg kell érteniük az ügyfelek kívánságait. Ez részben azt jelenti, hogy a jelenlegi ügyfelek visszajelzéseit megfigyeljük, nyomon követjük a közösségi oldalak eseményeit, és alaposan elemezzük a versenykörnyezetet. Ugyanakkor azt is jelenti, hogy meghallgatjuk, mit mondanak az ügyfelek másokról, és mit keresnek a piacon azok, akik még nem az ügyfeleink.

- $\quad$ A biztosítóknak nem szabad abba a hibába esniük, hogy a jelenlegi ügyfeleikre és versenytársaikra rutinfeladatként és lehetséges zavaró tényezőként tekintsenek.

- Sok esetben a biztosítók azt is figyelembe akarják venni egy-egy innováció esetében, hogy az összes ügyfelüknek megfelel-e az újítás.

- A biztosítóknak többet kellene tenniük az ügyfélközpontúságért. Azzal, hogy bevonják ügyfeleiket az újításba az innováció teljes ciklusán keresztül - tervezés, fejlesztés, eladás -, biztosítottá válik számukra az egész innovációs beruházás folyamatának kontrollálhatósága és összhangba állítása az ügyfélelvárásokkal.

\section{Innovációs kultúra létrehozása}

• Találja meg és fejlessze a meglévő jó képességű munkatársak közül azokat, akiktől új ötletek várhatóak, akik a folyamatok leegyszerüsítésével eddig is segítették a változást, és a jövőbe tekintettek!

- Amikor alkalmaz valakit, fogalmazza meg a szükséges új képességeket és adottságokat, amelyek a sokoldalú munkaerőre jellemzőek, azaz olyanra, aki képes tükrözni az elérni kívánt vállalati kultúrát!

- Bátorítsa a különböző munkamódszereket jutalmazás, szervezeti kultúra, tehetségstratégia, teljesítménymenedzsment útján!

- Fogadja el a kísérletezés szükségességét, és tegye azt központi kérdéssé a vállalati kultúrájukban! El kell fogadnia, hogy a hibáknak ugyan van kockázata, de úgy kell tekinteni rájuk, mint tanulási tapasztalatra.

\section{Bátorítsa a változást a vállalati kultúra átalakításán keresztül!}

A biztosítási üzletág legtöbb résztvevője felismeri, hogy a munkavállalók képviselik számukra az új ötletek lehetséges legnagyobb potenciálját. Sokan megpróbálták átalakítani a vállalati kultúrát a nagyobb innováció bátorításának érdekében. A tapasztalatok és a felmérés eredményei is azt jelzik viszont, hogy a vállalati kultúra megváltoztatása kényes pont marad a biztosítási szektor számára, amin azonban mindenképpen felül kell kerekedni. 
A válaszadóink fele szerint azzal, hogy jelenleg az új ötleteket többnyire több területet átfogó csapatok sokszínű munkacsoportjai találják ki, világosnak tűnik, hogy egy együttműködőbb kultúra létrehozásával a biztosítók képesek ösztönözni a hatékony innovációt.

\section{A munkavállalók képviselik az új ötletek lehetséges legnagyobb potenciálját.}

Míg néhányan a még innovatívabb kultúra létrehozására összpontosítanak, mások lényegesebben ügyfélcentrikusabb kultúrát teremtenek, amely közvetve képes ösztönözni az innovációt.

Mégis - a válaszadók fele szerint - a szervezeti hatékonyság növelésének nehézsége jelentős kihívást jelent az innováció számára. Úgy tűnik, hogy a kisebb szervezeteknek kevesebb ilyen kihívással kell szembenézniük, ami valószínűleg a kevésbé komplex struktúrájukat és a nagyobb együttműködés lehetőségét tükrözi.

\section{KPMG-megállapítás:}

- Érdemes ösztönözni a munkavállalókat, és olyan struktúrákat létrehozni, amelyek az ügyfelek sikerét - és nem a terméket - elötérbe helyezve támogatják a vállalati kultúra változását és az új gondolkodásmódra való átállást.

- Olyan rendszerekre, eszközökre és technológiákra van szükség, amelyek segítik az egyes ügyfél-interakciók értékének követését és az együttes ügyféltapasztalatokkal való összevetését, illetve a kultúraváltoztatás céljainak meghatározását.

- A siker egyik kulcstényezője a merev szervezeti struktúrák megszüntetése, és ezáltal együttműködőbb és rugalmasabb szervezet létrehozása.

\section{Szükséges intézkedések:}

- Azonosítsa az innovációk és a szervezetében már hatékonyan működő modellek jól elkülöníthető csoportját, hogy le tudja másolni azokat!

- Tekintse át a szélesebb körü tehetséggondozási stratégiát és a vállalati kultúrát! Fókuszáljon a vállalaton belüli tehetséges emberek sokszínủ csoportjának kialakítására, találja meg azokat a munkatársakat, akikről köztudott, hogy új ötletekkel, a folyamatok leegyszerűsítésével eddig is segítették a változást, és a jövőbe tekintettek!

- $\quad$ Fontolja meg a munkavállalói jutalmazást és a teljesítménymenedzsmentet, és gondolja át, hogy a mérőszámok és a célok vajon ösztönzik-e az innovációt és a kísérletezést!

\section{Legyen kész lépni!}

A „többé-kevésbé ugyanazt tenni, csak gyorsabban” nem jó recept a hosszú távú növekedésre. Az elöretekintő piaci szereplő felismeri annak szükségességét, hogy ne csak a termék és szolgáltatás fejlesztésében újítson, hanem abban is, hogyan közelítse meg magát az innovációt. A biztosítóknak és a közvetítőknek késznek kell lenniük új modellek elfogadására és az új résztvevőkkel való együttműködésre, hiszen csak így lehetnek valóban versenyképesek.

Lehet, hogy sok biztosító felismeri azt, hogy nem rendelkezik a szükséges képességekkel és adottságokkal, és elfogadja az innováció új modelljét. Tízből majdnem hét válaszadó nyilatkozott úgy, hogy inkább hisz az olyan együttműködésben, amelyben lehetőséget lát a jövőbeli innovációra, mintsem a vállalaton belüli erőfeszítésekben. A válaszadók 59 százaléka számolt be arról, hogy külsős tanácsadók és szaktanácsadók bevonásával már dolgoznak azon, hogy ösztönözzék az innovációt, 43 százalékuk pedig a partneri kapcsolat és együttműködés kialakításának céljából akadémikusokat és harmadik feleket keresett meg.

$\mathrm{Az}$ együttműködés legerősebb motivációja az új tehetségekhez és ötletekhez való hozzáférés. A válaszadók közel egynegyede reméli, hogy a szövetség segítségükre lesz a gyorsaság javításában és az új ötletek piaci bevezetésében. Meglepő azonban, hogy a válaszadóknak csak a 4 százaléka mondta, hogy az innováció költségének és a kockázat mérséklésének érdekében lépnek partneri kapcsolatra. A viszontbiztosítók számára az innováció nagyrészt a szállítókkal való együttmüködést jelenti.

Míg sokan külső forrásokból merítenek új ötleteket, addig mások sokkal inkább a magukénak érzik a feladatot. A megkérdezettek több mint egyharmada (36\%) számolt be arról, hogy innovációs központot és labort hoztak létre az elmúlt öt évben, valamint több mint az egynegyedük (27\%) rendelkezik olyan csapattal, amely teljesen elkötelezett az innováció iránt. Néhány biztosító elvetette ezt a megközelítést, előnyben részesítve az innováció felelősségének megosztását a tágabb értelemben vett szervezetben. Mások arra fókuszáltak, hogy ismételten felülvizsgálják és javítsák a már meglévő folyamatokat, ezáltal támogatva az innovációt.

\section{KPMG-megállapítás:}

- Ahhoz, hogy valóban profitálhassunk az együttműködésekből, egységben kell gondolkodnunk az ügyfelekről, a részvényesekről, a disztribútorokról és a beszállítókról - a teljes ökorendszerről -, valamint arról, hogy az együttműködés hogyan nyújt értéket minden egyes fél számára.

- Bár az adott cél érdekében létrehozott központok és laborok rövid távon ösztönzik az innovációt, a szervezeteknek módot kell találniuk arra, hogy az új ötleteket az alapvető üzleti tevékenységükbe integrálják. 


\section{Szükséges intézkedések:}

- Kötelezze el magát a fő részvényesekkel, beszállítókkal és ügyfelekkel együtt, hogy felfedezzék a partneri kapcsolatokban és szövetségekben rejlő innovációs lehetőségeket!

- Folyamatosan kutassa a lehetséges új, piaci zavarokat előidéző szereplöket és az innováció katalizátorait, és mérje fel, hogyan tudja versenytársait semlegesíteni vagy bekebelezni, társulni velük vagy védekezni ellenük, vagy csökkenteni a felmerülő kockázatokat!

- Hozzon létre és támogassa az ügyfélfórumokat, amelyekkel folyamatos innovációt építhet a már létező üzleti tevékenységébe és müködő modelljébe!

\section{Alkalmazzon agilis és elkötelezett vezetést!}

A tapasztalatok azt mutatják, hogy az erős, agilis és elkötelezett vezetőség és az innováció iránti felelősségvállalás a siker meghatározó tényezője lehet.

- Az innováció erős vezetői támogatást és világos víziót igényel. Mégis a válaszadók 40 százaléka szerint ahelyett, hogy a vezetés egyértelmű felelősséget vállalna az újítások irányításában, az innováció iránti felelősség informálisan az egész közösség tagjai között oszlik meg. További 31 százalék gondolja, hogy az innováció formálisabb, kollektív felelősség. Csupán 11 százalék állította, hogy a vállalatnál a vezetők közül egyvalaki (vagy egy csapat) felel az innovációért.

\section{— Az innováció erős vezetői támogatást és világos víziót igényel.}

Míg 44 százalék azt állította, hogy az innováció minden alkalommal napirendre kerül az igazgatótanácsi üléseken, ez gyakran olyan napirendi pont, amelyet csak évente egyszer vitatnak meg igazgatótanácsi szinten, ugyanakkor 9 százalék szerint sosem beszélnek az innovációról ezeken az alkalmakon. A vezetői tréningek, fejlesztések és az ösztönzés kulcsfontosságúak lesznek a jövőben. „Az innováció egyik sokat emlegetett kihívása a biztosítási szektorban a vezetők ösztönzésére vezethető vissza. A legtöbb szervezetnél azokat léptetik elő, akik nem sok vizet zavarnak. Ehelyett éppen azon kellene gondolkodniuk a szervezeteknek, hogyan jutalmazzák azokat az embereket, akik próbálkoznak, kísérleteznek, szemben azzal, hogy büntetik őket, ha ilyenkor kudarcot vallanak" - hangsúlyozta Gary Reader, a KPMG International biztosítási ágazatának globális vezetője.

\section{KPMG-megállapítás:}

- Önmagában az, ha elszámolhatósággal ruháznak fel bizonyos igazgatótanácsi tagokat vagy vezetőket, nem elegendő a transzformációs változás ösztönzésére. Az igazgatótanácsnak és a vezetőségnek aktív szerepet kell vállalnia az innováció ösztönzésében.
- A vezetőknek meg kell találniuk az egyensúlyt a gyorsaság és a kontrollok megtartása között az innovációs kultúra fejlesztése érdekében.

\section{Szükséges tennivalók:}

- Bizonyosodjon meg arról, hogy a vezetőség és az igazgatótanács érti az innováció kényszerítő erejének valódi hatását!

- Ruházza át az innováció felelősségét, és az igazgatótanács segítségével támogassa megfelelő forrásokkal, irányítással és megbízással az egész vállalatra kiterjedő ösztönzési programokat és kezdeményezéseket!

- Összpontosítsa az innovációs erőfeszítéseit olyan stratégiailag releváns képességekre, mint a fö folyamatok digitalizálása!

- Bátorítsa a szervezet minden szintjét, hogy vegyenek részt az innovációs kihívásokban és versenyekben! A jó ötletek gyakran a napi feladatokat ellátó, fontos pozíciókban dolgozóktól jönnek.

\section{Értse a beruházás miértjét!}

Egy régi mondás úgy tartja, nem tudod irányítani azt, amit nem tudsz mérni. Mégis a válaszadók kevesebb mint fele nyilatkozott úgy, hogy rendelkeznek olyan formális innovációs stratégiával, amely a befektetési döntésük irányítását segíti, és többnyire hiányoznak a célkitüzések és a siker méréséhez szükséges mérőszámok is.

Míg a legtöbb szervezet valamilyen módon méri innovációs befektetésük megtérülését, a tapasztalat azt mutatja, hogy csak néhányuk célja, hogy valóban megértsék, befektetésük miként ösztönzi a növekedést.

A kutatásunkban öt válaszadó közül több mint egy (20\%) bevallotta, hogy nem rendelkezik olyan formális eljárással, amellyel mérni tudja az innovációra fordított beruházás értékét. Amikor egy lehetséges felsorolást mutattunk a mérőszámokról, 42 százalék egyszerűen kipipálta az „az alábbi összes” jelölőnégyzetet, azt sugallva, hogy nem világos, hogyan is kellene valójában mérni a befektetés megtérülését.

\section{Többnyire hiányoznak a célkitüzések és a siker méréséhez szuik- séges mérőszámok.}

Azok, akik kiválasztottak egy adott mérőszámot, hajlottak arra, hogy a pénzügyi előnyök mentén érdemes a megfelelő választ keresni. A jövedelmezőség szerepelt az első helyen, míg a bevételnövekedés csak negyedik volt a rangsorban. Mások sokkal szubjektívebb mérőszámokra fókuszáltak, úgymint a hírnév vagy az ügyfél-elkötelezettség (a második, illetve a harmadik helyen). 


\section{KPMG-megállapítás}

- Azinnováció irányításánakés a mérőszámoknak a hiánya egyre kritikusabb a biztosítók és a közvetítők számára. A mérés képessége és az innovációs programok figyelemmel kísérése kulcsfontosságú annak megértésében, mely lépések biztosítják a legjobb eredményeket, illetve melyek hoznak folyamatos javulást a szervezeten belül.

- A pénzügyi mérőszámok fontosak, de lehet, hogy néhány innovációnak több költségvetési ciklusban is szerepelnie kell, amíg megvalósul. Egyensúlyt kell teremteni a pénzügyi eredmény és a hosszú távú célkitűzések között.

\section{Szükséges tennivalók:}

- Hívjon össze egy több területet átfogó csapatot egy szervezeten átívelő erőteljes és koherens innovációs stratégia megfogalmazásának és kifejlesztésének elősegítésére!

- Biztosítsa, hogy az innovációs programokat és kezdeményezéseket világos, mérhető és releváns célkitűzések támogassák!

- Alkossa meg azt az egész vállalatra kiterjedő innovációs stratégiát, amely világos szerepeket, felelősségeket, mérőszámokat és irányítást tartalmaz!

\section{Tanuljon másoktól!}

Sok, önmagát „gyors követőnek” vélő válaszadó biztosítónak kellene törekednie arra, hogy ne csak az új belépő és a gyorsan reagáló versenytársaktól tanuljon, hanem a biztosítási szektoron kívül eső vállalatok példáiból is.

Míg a válaszadók kétötöde vallotta magát gyors követőnek, kétharmaduk úgy nyilatkozott, hogy más iparági gyakorlatokat is figyelembe vesznek. Tízből csak egy válaszadó mondta, hogy új ötleteik elsősorban ilyen irányú versenytárs- és piacfigyelésből származnak.

Azok, akik más iparágakra is figyelnek, különösen a technológiai szektort követik nyomon, amelyet nemcsak jó tapasztalatszerzési forrásnak tartanak, hanem olyan szegmensnek, amelynek szereplöi képesek a biztosítási értékláncban zavarokat okozni. A banki és pénzügyi, telekommunikációs, média és elektronikai, szoftver és üzleti szolgáltató cégeket is lehetséges partnerként vagy éppen jövőbeni versenytársként tanulmányozzák behatóan.

A tapasztalatok azt mutatják, hogy a vezető szervezetek sokat tanulhatnak más iparágak sikereiből és bukásaiból

\section{KPMG-megállapítás:}

- Akik szakítanának a hagyományokkal, példaként a ritkábban említett üzleti szektorokat vizsgálják - mint például a kiskereskedelmi vagy a légitársaság-szektorokat -, hogy új ötleteket találjanak
- Megfigyelhető, hogy a biztosítók szorosabb kapcsolatot építenek ki technológiai vállalatokkal és kereskedelmi vállalkozásokkal, hogy a legjobb gyakorlatokat és az innovációs lehetőségeket megvitassák. Ilyenkor valójában úgy tekintenek magukra, mintha maguk is technológiai vállalatok és kereskedők lennének.

- Az együttmüködés növelése az érett szakaszban járó piaci résztvevők és a lehetséges piaci zavarokat elöidéző szereplők között segíti az innovációs célkitűzések elérését.

\section{Szüikséges tennivalók:}

- Csatlakozzon vagy építsen ki konzorciumokat, amelyek összehozzák a piaci szereplők sokaságát, beleértve azokat is, akik a biztosítási szektoron kívül tevékenykednek! Különösen olyan fórumokhoz csatlakozzon, amelyek az új technológiák sztenderdjeinek létrehozására összpontosítanak!

\section{Az innovációs elköteleződés kiemelten fontos: maga a lehetőségek tárháza}

\section{Mit kellene tenniük a biztosítók vezetőinek?}

Kutatásaink eredményei azt jelzik, hogy a legjobb lehetőségek megragadása érdekében a biztosítási szektornak a tradicionálisan kockázatkerülő kultúrából olyanra kell váltania, amely egyidejűleg ösztönzi az újítást, és csökkenti a pénzügyi kockázatot. Ennek eléréséhez a biztosítóknak új innovációs forrásokat kell felszabadítaniuk, és olyan friss ötletekre kell szert tenniük, amelyek származhatnak akár munkavállalóktól, ügyfelektől, befektetőktől vagy partnerektől, és a szervezet élén progresszív vezetést igényelnek.

\section{A növekedést elösegítö 10 szükséges tennivaló:}

1. Alkalmazzon agilis és elkötelezett vezetést!

2. Ösztönözze a változást a vállalati kultúra átalakításával!

Keressen kimagaslóan teljesítő embereket!

Értse, hogy miért fektet be!

Határozza meg, vállalati szervezete hogyan fog fejlődni, amint a biztositási ipar átalakul!

Tanuljon másoktól!

7. Alakítsa ki véleményét arra vonatkozóan, hogy a technológiai fejlesztések mikor és hogyan gyakorolnak majd hatást a szervezetére!

8. Használja ki az új technológiákat a jelenleg működő üzleti vállalkozásában

9. Enyhítse a kockázatot befektetés és kísérletezés útján!

10. Legyen kész átalakítani létező üzleti modelljeit!

Közremüködő vállalatok:

MetLife, Munich Reinsurance Company, Swiss Re, Poste Vita Group, Bought By Many, LIME, Beagle Street, AMP, Reinsurance Group of America (RGA), MAPFRE, Insurance 